\title{
Combined Foliar Spray of Boron, Calcium, and Silicon can Influence Quality and Shelf Life of Cherry Tomato in Modified Atmosphere Packaging
}

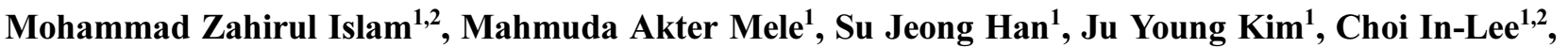 \\ Jae Su Yoon ${ }^{1}$, Hyuk Sung Yoon ${ }^{1}$, Jong-Man Park ${ }^{1}$, Il-Seop Kim ${ }^{1}$, Ki-Young Choi ${ }^{3}$, Ho- Min Kang ${ }^{1,2 *}$ \\ ${ }^{I}$ Department of Horticulture, Kangwon National University, Chuncheon 24341, Korea \\ ${ }^{2}$ Agriculture and Life Science Research Institute, Kangwon National University, Chuncheon 24341, Korea \\ ${ }^{3}$ Department of Controlled Agriculture, Kangwon National University, Chuncheon 24341, Korea
}

\begin{abstract}
This study was analyzed the effects of boron (B), calcium (Ca), silicon (Si) on quality and shelf life of 'Unicorn' cherry tomato at the light red maturity-stage. The storage conditions were modified atmosphere packaging (MAP) by oxygen transmission rate (OTR) packaging film at $5{ }^{\circ} \mathrm{C}, 11^{\circ} \mathrm{C}$, and $24^{\circ} \mathrm{C}$. Respiration and ethylene production were the lowest in $\mathrm{B}+\mathrm{Ca}+\mathrm{Si}$-treated tomato fruits. The lowest fresh weight loss and the longest shelf life resulted from the $\mathrm{B}+\mathrm{Ca}+\mathrm{Si}$ treatment. And the firmness was enhanced by $\mathrm{B}+\mathrm{Ca}+\mathrm{Si}$ treatment at harvest time, and it was retained after storage at $5^{\circ} \mathrm{C}, 11^{\circ} \mathrm{C}$, and $24^{\circ} \mathrm{C}$. Significantly lower soluble solids, lycopene, and color development were found at $\mathrm{B}+\mathrm{Ca}+\mathrm{Si}$-treated tomato fruits compared with control after storage. Moreover, the highest titratable acidity and vitamin $\mathrm{C}$ content were observed in $\mathrm{B}+\mathrm{Ca}+$ Si-treated tomato fruits after storage. From the above results, it was concluded that $\mathrm{B}+\mathrm{Ca}+\mathrm{Si}$ combined treatment can delay the maturity of cherry tomato after harvesting, and retained the firmness and prolong the shelf life.
\end{abstract}

Additional key words : ethylene, firmness, lycopene, respiration, soluble solids, vitamin C.

\section{Introduction}

Firmness is maintained due to an interaction of $\mathrm{Ca}$ in cell walls, where it binds to pectins and forms bridges between pectic acids, and as a result, the fruits get intact middle lamella (Madani et al., 2014). Ca increase fruit tissue by reducing respiration, maintaining ascorbic acid and membrane that maintained antioxidant ability, and thus fruits get firmness (Wang et al., 2014). Silicon ( $\mathrm{Si}$ ) is also a functional plant nutrient, and its deficiency in crops has been reported since 1970s (Laing et al., 2006) and it can increases the tomato fruits firmness (Weerahewa and David, 2015). Boron (B) is another vital element that influences cell wall formation to maintain the firmness of pear fruit (Khalaj et al., 2017). Si elicited polyphenol that can induce related genes and enzymes in the metabolic pathways, and avocado fruit's increase the ability against stress, and reduced lipid peroxidation, lessened electrolyte leakage and increased catalase activity (Tesfay et al., 2011).

Modified atmosphere packaging (MAP) of fresh prod-

*Corresponding author: hominkang@kangwon.ac.kr Received May 29, 2017; Revised August 29, 2017;

Accepted September 05, 2017 ucts can modify the micro atmosphere inside package, by natural reciprocation of two processes; the respiration of the product and the conveyance of gases in the packaging that leads to high carbon dioxide and low oxygen atmosphere (Mahajan, et al., 2007). Proper MAP can retain postharvest quality and shelf life (Islam et al., 2014).

Macro and micronutrients exist in the nutrient solution, however there was no combined foliar spray information about $\mathrm{B}+\mathrm{Ca}+\mathrm{Si}$. Moreover, no information that directly compared cherry tomato quality and shelf life after $\mathrm{B}+\mathrm{Ca}$ + Si pre-harvest treatment and MAP postharvest storage at $5^{\circ} \mathrm{C}, 11^{\circ} \mathrm{C}$, and $24^{\circ} \mathrm{C}$. The aim of this present research was to increase the cherry tomato quality and shelf life by using $\mathrm{B}+\mathrm{Ca}+\mathrm{Si}$ pre-harvest treatment and MAP storage as a postharvest condition at $5^{\circ} \mathrm{C}, 11^{\circ} \mathrm{C}$, and $24^{\circ} \mathrm{C}$.

\section{Materials and Methods}

Cherry tomatoes (Solanum lycopersicum cv. 'Unicorn') had grown in hydroponic system during summer at a plastic house in Korea. The supplied nutrient solution EC and $\mathrm{pH}$ were $2.3 \mathrm{dS} \cdot \mathrm{m}^{-1}$ and 5.8-6.2, respectively. Foliar spray treatments were started after bearing three trusses of tomato plants and they carried out once a week for five weeks. 
These treatments were : $1 \mathrm{M}$ calcium from calcium chloride (Goutam et al., 2010) $+20 \mathrm{mM}$ Si from silicon dioxide (Conceicao et al., 2014), and $4.85 \mathrm{mM}$ boron from boric acid (Davis et al., 2003) + $1 \mathrm{M}$ calcium from calcium chloride $+20 \mathrm{mM}$ Si from silicon dioxide. A tap water used as a control. Harvested light red maturity-stage tomatoes were used to measure the harvest time quality at room temperature $\left(20^{\circ} \mathrm{C}\right)$, and the rest were kept at $5^{\circ} \mathrm{C}$ and $11^{\circ} \mathrm{C}$ with $20,000 \mathrm{cc} / \mathrm{m}^{2}$ day atm oxygen transmission rate (OTR) packaging film as a MAP, and at $24^{\circ} \mathrm{C}$ with $40,000 \mathrm{cc}$ OTR packaging film as a MAP with $85 \%$ relative humidity to measure the fruit quality and shelf life.

Carbon dioxide and oxygen were measured by a PBI Dansensor (Check Mate 9900, Denmark). A GC-2010 Shimadzu chromatograph (Shimadzu Corporation, Japan), and equipped with a BP 20 wax column $(30 \mathrm{~m} \times 0.25 \mathrm{~mm}$ $\times 0.25 \mu \mathrm{m}$; SGE Analytical Science, Australia) and with a flame ionization detector was used to analyze ethylene. The detector and injector, ovens and carrier gas $\left(\mathrm{N}_{2}\right)$ flow rate were $127^{\circ} \mathrm{C}, 50^{\circ} \mathrm{C}$, and $0.67 \mathrm{~mL} / \mathrm{s}$, respectively (Mele et al., 2017).

Tomatoes fresh weight loss was measured by subtracting the tomato weights from their earlier measured weights and presented as percent of weight loss during the storage period. Tomatoes visual quality was observed on a scale of 1 to $5(1=$ very bad, $2=$ bad, $3=$ good, marketable, $4=$ very good, and $5=$ excellent) at $5^{\circ} \mathrm{C}, 11^{\circ} \mathrm{C}$, and $24^{\circ} \mathrm{C}$ by five panel members based on visual quality determinants such as mold growth, decay, shriveling, smoothness, shininess, and similarity (Jeong and Watkins, 2010). The firmness of tomato was measured by a rheometer (Sun Scientific Co. Ltd., Japan). Skin color values of tomatoes were analyzed by a chroma meter which model is CR-400 (Konica Minolta Sensing, Inc., Japan). In the chroma meter, $a^{*}$ and $b^{*}$ represented the degree of redness and yellowness, respectively (Mele et al., 2017). In this research, tomato redness was recorded as an $a^{*} / b^{*}$ value. The lycopene content was measured according to Fish et al. (2002), with a UV spectrophotometer (Shimadzu Corporation, Tokyo, Japan). The titratable acidity and soluble solid was measured by a DL22 food and beverage analyzer (Metter Toledo Ltd., Korea) and a refractometer (Atago USA Inc., USA), respectively. Vitamin $\mathrm{C}$ was analyzed by a HPLC (Waters Associates, Milford, MA, USA) which furnished by a $\mathrm{C}_{18}$ column $(4.6 \mathrm{~cm} \times 250 \mathrm{~mm} \times 5 \mu \mathrm{m}$; Agilent, USA $)$ at $265 \mathrm{~nm}$ (Mele et al., 2017). The mobile phase was 1
(100\% MeOH): $9\left(0.1 \mathrm{M} \mathrm{KH}_{2} \mathrm{PO}_{4}\right)$ with a $1.0 \mathrm{~mL} \mathrm{~min}^{-1}$ flow rate. A $20 \mu \mathrm{L}$ supernatant sample was prepared from $5 \%$ metaphosphoric acid of $2 \mathrm{~g}$ frozen homogenized tomato which filtered through a $0.20 \mu \mathrm{L}$ regenerated cellulose membrane.

Statistical analysis. The statistical analysis of all data was done by SPSS V. 16 (SPSS Inc., Chicago, USA), and the significant differences of the mean values were examined following the one-way ANOVA of Duncan's multiple range test (DMRT).

\section{Result and Discussions}

$\mathrm{B}+\mathrm{Ca}+\mathrm{Si}$-treatment had the lowest carbon dioxide and the highest oxygen concentration which leads to fresh tomato fruits. At $10^{\circ} \mathrm{C}-15^{\circ} \mathrm{C}, 3 \%-5 \%$ oxygen and $3 \%-5 \%$ carbon dioxide is a recommended MA atmosphere for ripe tomatoes during transport and/or storage (Kader, 2002), and our result at $5^{\circ} \mathrm{C}$ and $11^{\circ} \mathrm{C}$ was close to these findings. The current study agrees with Islam et al. (2014), that the proper MA condition at $5^{\circ} \mathrm{C}, 11^{\circ} \mathrm{C}$ and $24^{\circ} \mathrm{C}$ is $5 \%-9 \%$ carbon dioxide and $13 \%-16 \%$ oxygen, $5 \%-12 \%$ carbon dioxide and $11 \%-16 \%$ oxygen, and $9 \%-11 \%$ carbon dioxide and $12 \%-14 \%$ oxygen, respectively in tomato fruits. The carbon dioxide and oxygen composition of $\mathrm{B}+\mathrm{Ca}+\mathrm{Si}-$ treated tomatoes was similar to the tomatoes in a MA condition with $20,000 \mathrm{cc}$ at $5^{\circ} \mathrm{C}$ and $11^{\circ} \mathrm{C}$, and $40,000 \mathrm{cc}$ at $24^{\circ} \mathrm{C}$ (Fig. 1).

The control tomato fruits had the highest ethylene production; as a result, the tomatoes rapidly turned red and had a shorter shelf life. Ethylene reduced the kiwifruit firmness (Jabbar and East, 2016), and 0.5 ppm was threshold in tomato for ethylene action (Kader, 2002). The B $+\mathrm{Ca}+\mathrm{Si}-$ treated tomato fruits maintained lower ethylene production; as a result, the tomatoes had a prolonged shelf life (Fig. 1).

The fresh weight loss of $\mathrm{B}+\mathrm{Ca}+\mathrm{Si}$-treated tomato fruits at $5^{\circ} \mathrm{C}, 11^{\circ} \mathrm{C}$, and $24^{\circ} \mathrm{C}$ had $0.24 \%, 0.22 \%$, and $0.48 \%$, respectively, which can help prolong the shelf life by maintaining fresh tomato fruits (Fig. 2). As the storage temperatures increased, so the fresh weight loss was increased, and this happened because higher temperature leads to higher respiration and evaporation (Islam et al., 2014). The lowest fresh weight loss had in $\mathrm{B}+\mathrm{Ca}+\mathrm{Si}-$ treated tomato fruits because of lower transpiration (moisture loss), and lower respiration. This is in agreement with 

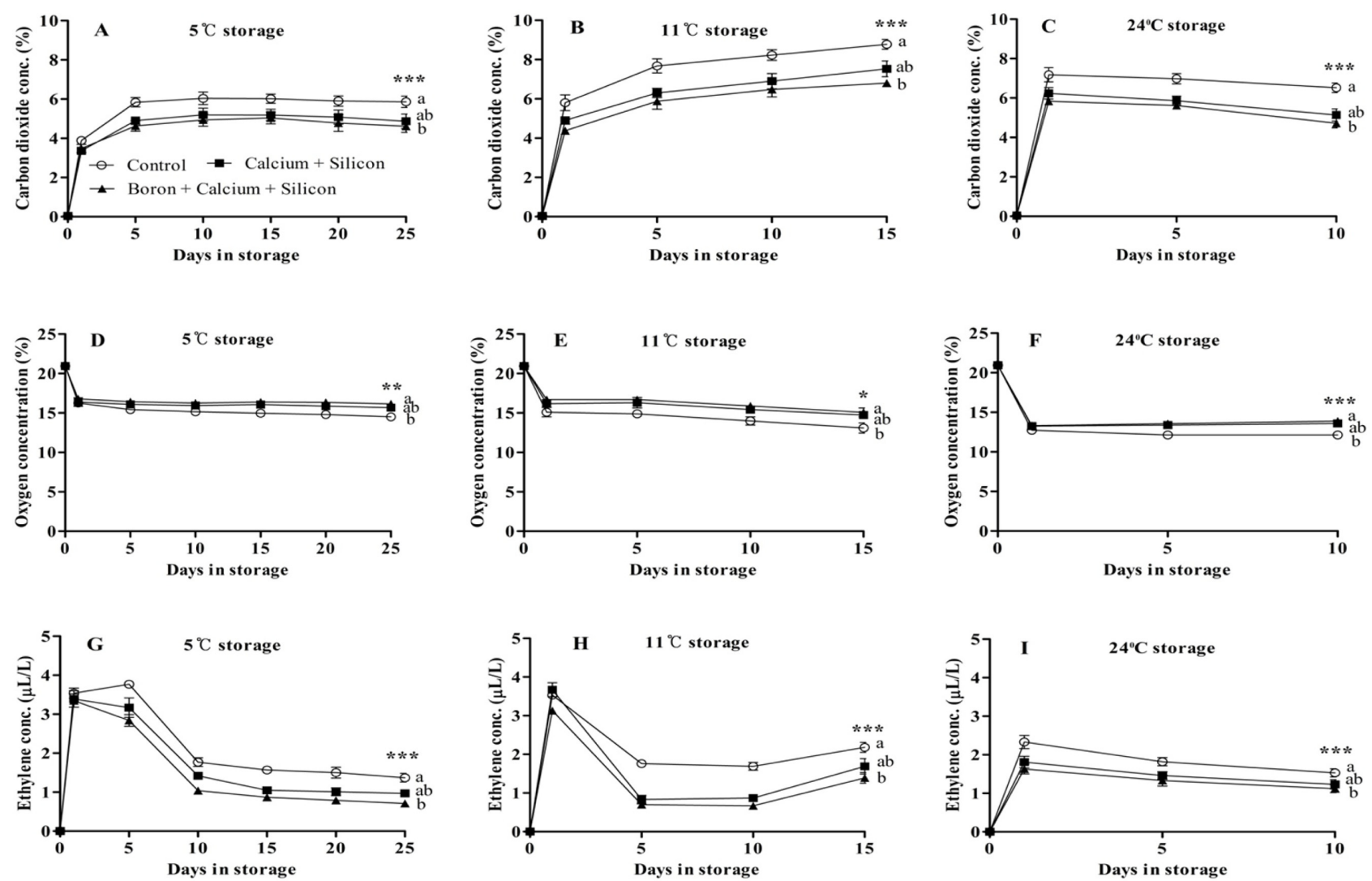

Fig. 1. Carbon dioxide (A, B and C), oxygen (D, E and F) and ethylene concentration (G, H and I) of cherry tomatoes at different storage temperatures. Data pointed by the mean \pm standard error $(\mathrm{n}=5){ }^{*},{ }^{* *},{ }^{* *}$; significant at $\mathrm{p} \leq 0.05,0.01$ and 0.001 of Duncan's multiple range tests (DMRT).
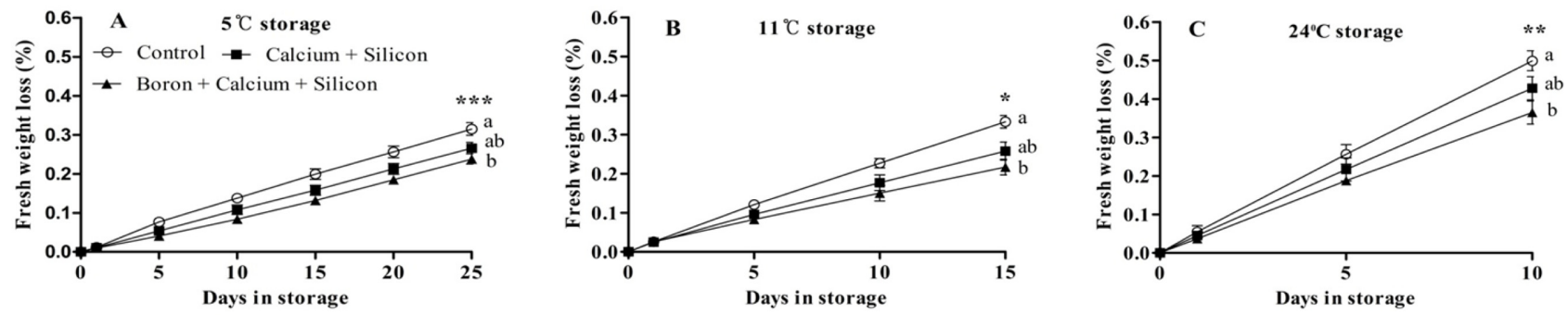

Fig. 2. Fresh weight loss (A, B and C) of tomatoes at $5^{\circ} \mathrm{C}, 11^{\circ} \mathrm{C}$, and $24^{\circ} \mathrm{C}$ storage temperatures. Data pointed by the mean \pm standard error $(\mathrm{n}=10) .{ }^{*}, * *, * * *$; significant at $\mathrm{p} \leq 0.05,0.01$ and 0.001 , respectively of Duncan's multiple range tests (DMRT)

Romero-Aranda et al. (2006), which the hydrophilic nature of Si maintains moisture in tomato fruit tissues by building a barrier to protect moisture loss through the cuticle via crystals deposited in the epidermal cells.

The $\mathrm{B}+\mathrm{Ca}+$ Si-treated tomato fruits had the longest shelf life because they maintained their marketable visual quality $(\geq 3)$ and freshness. The control, $\mathrm{Ca}+\mathrm{Si}-$, and $\mathrm{B}+$
$\mathrm{Ca}+$ Si-treated tomato fruits had shelf life of 19, 23, and 25 days, respectively, at $5^{\circ} \mathrm{C}$. Moreover, control, $\mathrm{Ca}+\mathrm{Si}$-, and $\mathrm{B}+\mathrm{Ca}+$ Si-treatment maintained ten, 13 , and 15 days shelf life, accordingly at $11^{\circ} \mathrm{C}$. At $24^{\circ} \mathrm{C}$, the control, $\mathrm{Ca}+$ $\mathrm{Si}$-, and $\mathrm{B}+\mathrm{Ca}+$ Si-treated tomato fruits had shelf life of 6, 8, and 10 days, respectively (Fig. 3). Senescent changes resulting in losses in physicochemical and nutritional quali- 

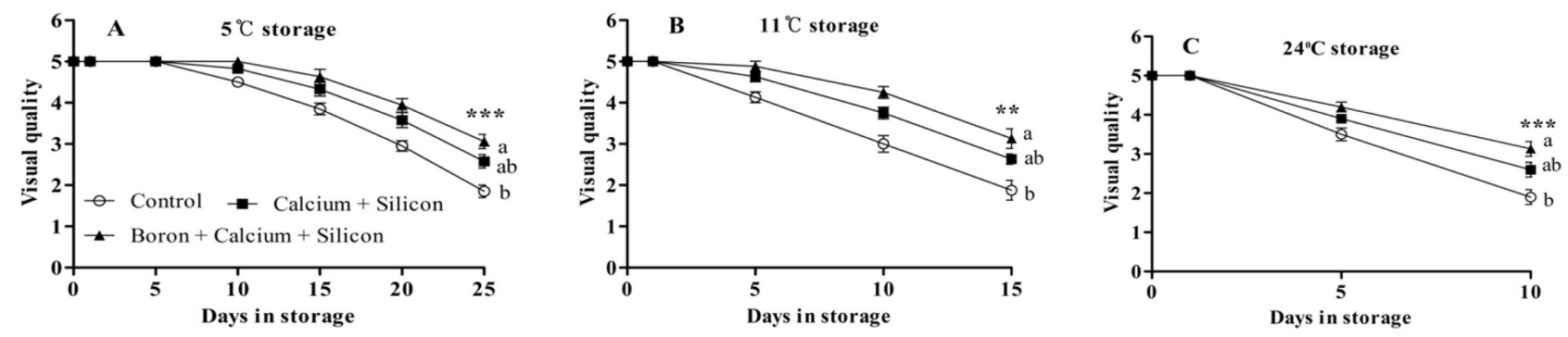

Fig. 3. Visual quality (A, B and C) of tomatoes at $5^{\circ} \mathrm{C}, 11^{\circ} \mathrm{C}$, and $24^{\circ} \mathrm{C}$ storage temperatures. The visual quality was observed on the scale 1-5 (5: excellent, 4: very good, 3: good, marketable, 2: bad and 1: waste) during at $5^{\circ} \mathrm{C}$ storage. Data pointed by the mean \pm standard error $(\mathrm{n}=10) . * * ; * *$; significant at $\mathrm{p} \leq 0.01$ and 0.001 , respectively of Duncan's multiple range tests (DMRT).

Table 1. Firmness, color and lycopene of cherry tomato which treated by boron (B), calcium (Ca) and silicon (Si) with MAP (20,000 cc OTR packaging film at $5^{\circ} \mathrm{C}$ and $11^{\circ} \mathrm{C}$, and $40,000 \mathrm{cc}$ OTR packaging film at $24^{\circ} \mathrm{C}$ ).

\begin{tabular}{|c|c|c|c|c|c|c|c|c|c|c|c|c|}
\hline \multirow{2}{*}{$\begin{array}{c}\text { Treatments } \\
\text { Storage temp. }\end{array}$} & \multicolumn{4}{|c|}{$\begin{array}{l}\text { Firmness } \\
(\mathrm{N})\end{array}$} & \multicolumn{4}{|c|}{$\begin{array}{l}\text { Color } \\
\left(\mathrm{a}^{*} / \mathrm{b}^{*}\right)\end{array}$} & \multicolumn{4}{|c|}{$\begin{array}{c}\text { Lycopene } \\
\text { (mg /kg FW) }\end{array}$} \\
\hline & Harvest & $\begin{array}{c}5^{\circ} \mathrm{C} \\
(25 \text { days })\end{array}$ & $\begin{array}{c}11^{\circ} \mathrm{C} \\
(15 \text { days })\end{array}$ & $\begin{array}{c}24^{\circ} \mathrm{C} \\
\text { (10days) }\end{array}$ & Harvest & $\begin{array}{c}5^{\circ} \mathrm{C} \\
(25 \text { days })\end{array}$ & $\begin{array}{c}11^{\circ} \mathrm{C} \\
\text { (15days) }\end{array}$ & $\begin{array}{c}24^{\circ} \mathrm{C} \\
\text { (10days) }\end{array}$ & Harvest & $\begin{array}{c}5^{\circ} \mathrm{C} \\
\text { (25days) }\end{array}$ & $\begin{array}{c}11^{\circ} \mathrm{C} \\
\text { (15days) }\end{array}$ & $\begin{array}{c}24^{\circ} \mathrm{C} \\
\text { (10days) }\end{array}$ \\
\hline Control & $18.97 b^{z}$ & $12.50 \mathrm{~b}$ & $15.87 b$ & $14.09 \mathrm{~b}$ & $0.41 \mathrm{a}$ & $0.57 \mathrm{a}$ & $0.67 \mathrm{a}$ & $0.77 \mathrm{a}$ & $86.89 a$ & $119.12 \mathrm{a}$ & $140.67 \mathrm{a}$ & $160.56 a$ \\
\hline $\mathrm{Ca}+\mathrm{Si}$ & $22.17 \mathrm{ab}$ & $15.18 \mathrm{ab}$ & $17.62 \mathrm{ab}$ & $16.15 \mathrm{ab}$ & $0.41 \mathrm{a}$ & $0.55 \mathrm{ab}$ & $0.64 \mathrm{ab}$ & $0.75 \mathrm{ab}$ & $85.28 \mathrm{a}$ & $109.44 \mathrm{ab}$ & $132.28 \mathrm{ab}$ & $152.71 \mathrm{ab}$ \\
\hline $\mathrm{B}+\mathrm{Ca}+\mathrm{Si}$ & $24.31 \mathrm{a}$ & $16.92 \mathrm{a}$ & $18.22 \mathrm{a}$ & $17.63 \mathrm{a}$ & $0.42 \mathrm{a}$ & $0.52 b$ & $0.60 \mathrm{~b}$ & $0.72 b$ & $84.73 \mathrm{a}$ & $104.99 \mathrm{~b}$ & $126.52 b$ & $144.63 b$ \\
\hline $\mathrm{P}$ values & $* * *$ & $* * *$ & $* *$ & $* * *$ & NS & $* *$ & $* *$ & $* *$ & NS & $*$ & $*$ & $*$ \\
\hline
\end{tabular}

${ }_{\mathrm{Z}}$ Mean assay within columns of Duncan's multiple range tests (DMRT) $(\mathrm{n}=5) . \mathrm{NS},{ }^{*},{ }^{* *},{ }^{* * *}$ : not significant, and significant at $\mathrm{p} \leq 0.05$, 0.01 and 0.001 , respectively.

ties can be inhibited, and the fruit storage life could be markedly prolonged (Pila et al., 2010). B $+\mathrm{Ca}+\mathrm{Si}$ treatment improve the shelf life of tomatoes by lowering respiration, shriveling, and internal breakdown. High temperatures influence the tomato's respiration rate, which does not prolong the shelf life (Islam et al., 2012).

$\mathrm{The} \mathrm{Ca}+\mathrm{Si}$-treated tomato fruits showed higher firmness compared with control both harvest time and after storage. Moreover, the $\mathrm{B}+\mathrm{Ca}+\mathrm{Si}$-treated tomato fruits showed the highest firmness among the treatments both harvest time and after storage. The $\mathrm{B}$ maintained the $\mathrm{Ca}-$ pectate associations (Davis et al., 2003) and Ca treatment increased the Ca-pectate by maintaining middle lamella (Hepler and Winship, 2010) which increase the tomato fruits firmness. The $\mathrm{B}+\mathrm{Ca}+\mathrm{Si}$-treated tomato fruits may cross-link pectin molecules in plant cell walls, and the metal binding stabilizes the cell-wall structure by the pectin network. $\mathrm{B}+\mathrm{Ca}+$ Si-treated tomato fruits showed the highest firmness due to lower respiration, ethylene production, and color development. The $\mathrm{B}+\mathrm{Ca}+$ Si-treated tomato maintained their firmness, which is desirable for long-time storage (Table 1).

There was no significant difference in quality parameters (color, lycopene, soluble solids, titratable acidity and vitamin C) at harvest time among the treatments, as we selected same maturity-stage fruits (light red) to do this experiment, but these fruits showed significant differences after storage in all storage temperatures.

Color is important to sellers, buyers, and consumers when choosing tomato fruits. The $\mathrm{B}+\mathrm{Ca}+\mathrm{Si}$-treated tomato fruits had lower color development than the other treatments due to lower respiration and ethylene production which help to prolong the shelf life. During fruit ripening, loss of tissue permeability and membrane integrity (Panarese et al., 2012) and color development leads the ripeness (Islam et al., 2013) that influenced by carbon dioxide and ethylene, thus deteriorates tomato quality and shortens the shelf life.

The maturity stages of tomato fruits influence the lycopene content. The $\mathrm{B}+\mathrm{Ca}+$ Si-treated tomato fruits had the lowest lycopene content among the treatments (Table 1). There is a big difference in the lycopene content in red- 
Table 2. Soluble solids, titratable acidity and vitamin $\mathrm{C}$ content of cherry tomato which treated by boron (B), calcium (Ca) and silicon (Si) with MAP $\left(20,000 \mathrm{cc}\right.$ OTR packaging film at $5^{\circ} \mathrm{C}$ and $11^{\circ} \mathrm{C}$, and $40,000 \mathrm{cc}$ OTR packaging film at $\left.24^{\circ} \mathrm{C}\right)$.

\begin{tabular}{|c|c|c|c|c|c|c|c|c|c|c|c|c|}
\hline \multirow{2}{*}{$\begin{array}{c}\text { Treatments } \\
\text { Storage temp. }\end{array}$} & \multicolumn{4}{|c|}{$\begin{array}{l}\text { Soluble solids } \\
\text { ( }{ }^{\circ} \text { Brix) }\end{array}$} & \multicolumn{4}{|c|}{$\begin{array}{l}\text { Titratable acidity } \\
\text { (\% citric acid) }\end{array}$} & \multicolumn{4}{|c|}{$\begin{array}{c}\text { Vitamin C } \\
(\mathrm{mg} / 100 \mathrm{~g} \mathrm{FW})\end{array}$} \\
\hline & Harvest & $\begin{array}{c}5^{\circ} \mathrm{C} \\
(25 \text { days })\end{array}$ & $\begin{array}{c}11^{\circ} \mathrm{C} \\
(15 \text { days })\end{array}$ & $\begin{array}{c}24^{\circ} \mathrm{C} \\
\text { (10days) }\end{array}$ & Harvest & $\begin{array}{c}5^{\circ} \mathrm{C} \\
(25 \text { days })\end{array}$ & $\begin{array}{c}11^{\circ} \mathrm{C} \\
\text { (15days) }\end{array}$ & $\begin{array}{c}24^{\circ} \mathrm{C} \\
\text { (10days) }\end{array}$ & Harvest & $\begin{array}{c}5^{\circ} \mathrm{C} \\
(25 \text { days })\end{array}$ & $\begin{array}{c}11^{\circ} \mathrm{C} \\
\text { (15days) }\end{array}$ & $\begin{array}{c}24^{\circ} \mathrm{C} \\
\text { (10days) }\end{array}$ \\
\hline Control & $7.27 \mathrm{a}^{\mathrm{z}}$ & $7.50 \mathrm{a}$ & $7.57 \mathrm{a}$ & $7.59 \mathrm{a}$ & $0.68 \mathrm{a}$ & $0.57 \mathrm{~b}$ & $0.38 \mathrm{~b}$ & $0.37 \mathrm{~b}$ & $15.69 \mathrm{a}$ & $8.75 b$ & $12.65 b$ & $9.94 \mathrm{~b}$ \\
\hline $\mathrm{Ca}+\mathrm{Si}$ & $7.16 \mathrm{a}$ & $7.25 \mathrm{ab}$ & $7.35 \mathrm{ab}$ & 7.37ab & $0.69 \mathrm{a}$ & $0.64 \mathrm{ab}$ & $0.45 \mathrm{ab}$ & $0.42 \mathrm{ab}$ & $16.74 \mathrm{a}$ & 10.13ab & $14.41 \mathrm{ab}$ & $12.05 \mathrm{ab}$ \\
\hline $\mathrm{B}+\mathrm{Ca}+\mathrm{Si}$ & $7.11 \mathrm{a}$ & $7.19 b$ & $7.23 b$ & $7.28 b$ & $0.71 \mathrm{a}$ & $0.69 \mathrm{a}$ & $0.53 \mathrm{a}$ & $0.51 \mathrm{a}$ & $16.98 \mathrm{a}$ & $11.15 \mathrm{a}$ & $15.62 \mathrm{a}$ & $13.65 \mathrm{a}$ \\
\hline $\mathrm{P}$ values & NS & $*$ & $*$ & $* *$ & NS & $* *$ & $* *$ & $* *$ & NS & $*$ & $*$ & $* *$ \\
\hline
\end{tabular}

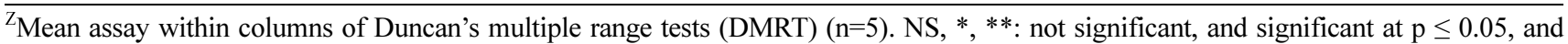
0.01 , respectively.

and deep-red-stage tomato fruits (Brandt et al., 2006). The control had rapid color development; thus, the fruits lost quality, market value, and shelf life quickly. However, the control had the highest soluble solids after storage and this is in agreement with Nath et al. (2012), that soluble solids may increase because of excessive moisture loss thus stimulate the hydrolysis of carbohydrates to soluble sugars. Moreover, $\mathrm{Ca}$ treatment maintains the lowest metabolic activity during fruit storage (Goutam et al., 2010). B $+\mathrm{Ca}+$ Si-treated tomato fruit can form a protective barrier, and the tissue permeability and cellular metabolic changes which can slow down color development, lycopene, and soluble solids by lowering respiration, ethylene production and ripening, consequently tomatoes get prolonged shelf life.

The $\mathrm{B}+\mathrm{Ca}+$ Si-treated tomato fruits had higher titratable acidity and vitamin $\mathrm{C}$ content than the other treatments (Table 2). Higher acidity retained by Ca-treatment due to delay ripening process and low respiration rate during storage period in Guava (Goutam et al., 2010). Moreover, the reduced rate of metabolic activities has implication for better vitamin C (Tigist et al., 2013). The titratable acidity and vitamin $\mathrm{C}$ content were maintained in the $\mathrm{B}+\mathrm{C}+\mathrm{Si}$-treated tomato fruits after storage because of lower respiration, ethylene production, ripening, and metabolic activities.

\section{Conclusion}

$\mathrm{B}+\mathrm{Ca}+\mathrm{Si}$ pre-harvest treatment and MAP storage as a postharvest condition was evaluated to know the cherry tomato quality and shelf life at $5^{\circ} \mathrm{C}, 11^{\circ} \mathrm{C}$, and $24^{\circ} \mathrm{C}$. The application of $\mathrm{B}+\mathrm{Ca}+\mathrm{Si}$ increases fruit firmness at harvest time. $\mathrm{B}+\mathrm{Ca}+\mathrm{Si}$ treatment decreases carbon dioxide, ethylene, fresh weight loss, color, lycopene, and soluble solids during storage in all storage temperatures. Moreover, $\mathrm{B}+\mathrm{Ca}+$ Si-treated tomato fruits retained their oxygen level, visual quality, firmness, titratable acidity, and vitamin $\mathrm{C}$ content in all storage temperatures. The $\mathrm{B}+\mathrm{Ca}$ + Si treatment could help improve the cherry tomato quality, shelf life and may offer an economical value to the grower, seller, buyer, and/or consumer.

\section{Acknowledgements}

This research was supported by Export Promotion Technology Development Program (314027-3), IPET (Korea Institute of Planning and Evaluation for Technology in Food, Agriculture, Forestry and Fisheries), Ministry of Agriculture, Food and Rural Affairs, Korea.

\section{Literature Cited}

Brandt, S., Z. Pek, E. Barna, A.Lugasi, and L. Helyes. 2006. Lycopene content and colour of ripening tomatoes as affected by environmental conditions. J. Sci. Food Agric. 86:568-572.

Davis, J.M., D.C. Sanders, P.V. Nelson, L. Lengnick, and W.J. Sperry. 2003. Boron improves growth, yield, quality, and nutrient content of tomato. J. Am. Soc. Hortic. Sci.128:441446.

Conceicao, C.S., K.C.S. Felix, R.L.R. Mariano, E.V. Medeiros, and E.B. Souza. 2014. Combined effect of yeast and silicon on the control of bacterial fruit blotch in melon. Sci. Hort. 174:164-170.

Fish, W.W., P. Perkins-Veazie, and J.K. Collins. 2002. A quantitative assay for lycopene that utilizes reduced volumes of organic solvents. J. Food Comp. Anal. 15:309-317.

Goutam, M., H.S. Dhaliwal, and B.V.C. Mahajan. 2010. Effect 
of pre-harvest calcium sprays on post-harvest life of winter guava (Psidium guajava L.). J. Food Sci. Technol. 47(5):501-506.

Hepler, P.K. and J.L. Winship. 2010. Calcium at the cell wallcytoplast interface. J. Integr. Plant Biol. 52(2):147-160.

Islam, M.Z., Y.S. Kim, and H.M. Kang. 2012. Effect of temperature on the quality and storability of cherry tomato during commercial handling condition. J. Bio-Environ. Control. 21(2):88-94.

Islam, M.Z., J.P. Baek, Y.S. Kim, and H.M. Kang. 2013. Characteristics of chilling symptoms of cherry tomato compared to beefsteak tomato harvested at different ripening stages. J. Pure Appl. Microbio. 7:703-709.

Islam, M.Z., M.A. Mele, H.J. Lee, K.S. Lee, S.M. Hong, M.J. Jeong, I.S. Kim, S.K. Hong, I.L. Choi, J.P. Baek and H.M. Kang. 2014. Selection of non-perforated breathable film to enhance storability of cherry tomato for modified atmosphere storage at different temperatures. Protected Hort. Plant Fac. 23:116-122.

Jabbar, A. and A.R. East. 2016. Quantifying the ethylene induced softening and low temperature breakdown of 'Hayward' kiwifruit in storage. Postharvest Biol. Technol. 113:87-94.

Jeong, C.S. and C.B. Watkins. 2010. Effects of mixed gas in active MA packaging on marketability maintenance at simulated tomato fruits marketing. Hort. Environ. Biotechnol. 51(3):184-188.

Kader, A. A. 2002. Postharvest technology of horticultural crops, p.1-519. Third edition, Publication 3329, Davis: University of California.

Khalaj, K., N. Ahmadi, and M. K. Souri. 2017. Improvement of postharvest quality of Asian pear fruits by foliar application of boron and calcium. Hortic. 3(15):1-8.

Laing, M.D., M. Gatarayiha, and A. Adandonon. 2006. Silicon use for pest control in agriculture: A review. Proc. S. Afr. Sug. Technol. Ass. 80:278-286.

Madani, B., M.T.M. Mohamed, C.B. Watkins, J. Kadir, Y. Awang, and T.R. Shojaei. 2014. Preharvest calcium chloride sprays affect ripening of Eksotika II'papaya fruits during cold storage. Sci. Hort. 171:6-13.
Mahajan, V.P., F.A.R. Oliveira, J.C. Montanez, and J. Frias. 2007. Development of user-friendly software for design of modified atmosphere packaging for fresh and fresh-cut produce. Innov. Food Sci. Emerg. Technol. 8:84-92.

Mele M.A., M.Z. Islam, J.P. Baek, and H.M. Kang. 2017. Quality, storability, and essential oil content of Ligularia fischeri during modified atmosphere packaging storage. J. Food Sci. Technol. 54(3):743 -750.

Nath, A., C.D. Bidyut, S. Akath, R.K. Patel, D. Paul, L.K. Misra and H. Ojha. 2012. Extension of shelf life of pear fruits using different packaging materials. J. Food Sci. Technol. 49(5):556-563.

Panarese, V., U. Tylewicz, P. Santagapita, P. Rocculi, and M. Dalla Rosa. 2012. Isothermal and differential scanning calorimetries to evaluate structural and metabolic alterations of osmo-dehydrated kiwifruit as a function of ripening stage. Innov. Food Sci. Emerg. Technol. 15:66-71.

Pila, N., N.B. Gol, and T.V.R. Rao. 2010. Effect of post-harvest treatments on physicochemical characteristics and shelf life of tomato (Lycopersicon esculentum Mill.) fruits during storage. Am-Euras. J. Agric. Environ. Sci. 9:470-479.

Romero-Aranda, M.R., O. Jurado, and J. Cuartero. 2006. Silicon alleviates the deleterious salt effect on tomato plant growth by improving plant water status. J. Plant Physiol. 163:847-855.

Tesfay, S.Z., I. Bertling, and J.P. Bower. 2011. Effects of postharvest potassium silicate application on phenolics and other anti-oxidant systems aligned to avocado fruit quality. Postharvest Biol. Technol. 60:92-99.

Tigist, M., T.S. Workneh, and K. Woldetsadik. 2013. Effects of variety on the quality of tomato stored under ambient conditions. J. Food Sci. Technol. 50(3):477-486.

Weerahewa, D. and D. David. 2015. Effect of silicon and potassium on tomato anthracnose and on the postharvest quality of tomato fruit (Lycopersicon esculentum Mill.). J. Natl. Sci. Found Sri. 43 (3):273-280.

Wang, Y., X. Xie and L.E. Long. 2014. The effect of postharvest calcium application in hydro-cooling water on tissue calcium content, biochemical changes, and quality attributes of sweet cherry fruit. Food Chem. 16:22-30. 


\title{
붕소, 칼슘, 규소의 복합 엽면시비가 방울토마토의 품질과 $\mathrm{MAP}$ 조건에서 저장성에 미치는 영향
}

\author{
이슬람 모하메드 조히룰 ${ }^{1,2} \cdot$ 밀리 마하무다 악터 ${ }^{1} \cdot$ 한수정 $^{1} \cdot$ 김주영 ${ }^{1} \cdot$ 최인이 $^{1,2} \cdot$ 윤재수 $^{1}$ \\ 윤혁성 ${ }^{1} \cdot$ 박종만 $^{1} \cdot$ 김일섭 ${ }^{1} \cdot$ 최기영 ${ }^{3} \cdot$ 강호민 $^{1,2 *}$ \\ 1강원대학교 원예학과, ${ }^{2}$ 강원대학교 농업생명과학연구원, ${ }^{3}$ 강원대학교 시설농업학과
}

\begin{abstract}
적 요. 방울토마토의 수경재배 중 붕소+칼슘+규소 및 칼슘+규소의 복합 엽면시비가 수확 후 품질과 MAP 저장 중 저장성에 미치는 영향을 알아보고자 본 연구를 실시하였다. 엽면시비한 방울 토마토('Unicorn')는 반숙 과 상태에서 수확하여 산소투과성 필름으로 포장한 $5^{\circ} \mathrm{C}, 11^{\circ} \mathrm{C}$, 그리고 $24^{\circ} \mathrm{C}$ 에서 25 일, 15 일, 10 일간 저장하였 다. 붕소+칼슘+규소 복합처리한 방울토마토가 3가지 저장온도 모두에서 호흡과 에틸렌 발생이 억제되어 MAP 저장중 가장 낮은 생체중 감소와 가장 높은 외관상 품질을 보였다. 수확 후 조사한 방울토마토의 경도, 산도, 비타민 C 함량은 붕소+칼슘+규소 복합처리에서 가장 높았으며, 3 가지 온도 모두에서 MAP 저장 후에도 모두 높게 유지되었다. 그러나 과피색, 라이코펜 함량과 당도는 수확 후에는 엽면시비 처리로 차이가 없었으나, 3 가 지 온도 모두 붕소+칼슘+규소 복합처리에서 가장 낮은 수치를 보였다. 이상의 결과로 볼 때 붕소+칼슘+규소 복합처리는 방울토마토의 수확후 생리 작용을 억제하고 경도, 산도, 비타민 $\mathrm{C}$ 함량을 높여 저장성을 향상시키 는 것으로 판단되었다
\end{abstract}

추가 주제어 : 에틸렌, 경도, 라이코펜, 호흡, 당도, 비타민 C. 